\title{
POSTAWY STUDENTÓW WYBRANYCH KIERUNKÓW STUDIÓW WOBEC NIERÓWNOŚCI PŁCI W POLSCE*
}

\section{SPOŁECZNE NIERÓWNOŚCI PŁCI}

Przez długi czas zainteresowania nauk społecznych w zakresie problematyki nierówności społecznych skupiały się na zjawiskach stratyfikacji społecznej, istnienia $\mathrm{w}$ społeczeństwie hierarchicznego systemu warstw i klas społecznych różniących się dostępem do bogactwa, władzy i prestiżu. Wraz z rozwojem ruchu feministycznego i teorii feministycznych w drugiej połowie XX wieku (tzw. druga fala feminizmu) w badaniu różnic i nierówności między ludźmi pojawiła się nowa perspektywa. Jak pisze Henryk Domański (1992, s. 5, 18): "W latach siedemdziesiątych badacze struktury społecznej odkryli «nowe», nie analizowane przedtem płaszczyzny podziałów i nierówności. [...] Teorie feministyczne wprowadziły pewien ferment do konwencjonalnego schematu ujmowania zjawisk strukturalizacji. Zwrócono uwagę na nierówności płci jako płaszczyznę zróżnicowania społecznego, jakościowo różną od podziałów zawodowych i barier klasowo-warstwowych określonych przez stosunki własności i kierowania przedsiębiorstwami".

Nierówności płci są specyficzną formą nierówności społecznych. U podstaw ich istnienia leży bowiem zasadnicza różnica biologiczna między ludźmi. Jednak nie różnice $\mathrm{w}$ anatomii są tu kluczowe, ale ich społeczne konsekwencje — role i pozycje społeczne. Rozgranicza się aspekt biologiczny i społeczny kategorii płci, czyli odmienności anatomiczne i fizjologiczne między kobietami i mężczyznami, określane w języku angielskim terminem sex (płeć), oraz przypisywane kobietom i mężczyznom cechy, zachowania i wzory ról społecznych,

\section{Adres do korespondencji: kdzwonkowska@op.pl}

* W tekście odwołuję się do wyników badania własnego przedstawionego w pracy magisterskiej: K. Dzwonkowska, „Zbudować społeczeństwo egalitarne. Postawy studentów wobec nierówności płci w Polsce”, napisanej pod kierunkiem dr hab. Ewy Malinowskiej, Uniwersytet Łódzki, Łódź 2004. 
wynikające ze społecznej konstrukcji męskości i kobiecości, przyswajane przez jednostki w procesie socjalizacji, kształtowane odmiennie w różnych kulturach i epokach (por. Sekuła-Kwaśniewicz 2000; Gontarczyk 1995; Giddens 2004). Do kulturowych definicji męskości i kobiecości odnosi się angielskie pojęcie gender (dosłownie: rodzaj), tłumaczone na język polski jako „płeć w sensie kulturowym, płeć kulturowa lub społeczno-kulturowa rola płciowa" (Walczewska 2001, s. 81). Punktem wyjścia do oddzielenia biologicznego i kulturowo-społecznego aspektu płci było studium Margaret Mead z 1935 r. Pteć $i$ charakter $w$ trzech społecznościach pierwotnych, w którym autorka pokazała, że „każde społeczeństwo konstruuje własne reguły bycia kobietą lub mężczyzną, czyli tzw. wzorce kobiecości i męskości, w ramach których obu płciom stawia się wymagania zarówno pod względem pożądanych cech osobowości, jak i właściwych zachowań w ważnych dla życia zbiorowego dziedzinach" (Sekuła-Kwaśniewicz 2000, s. 122). Powołujące się na tę pracę „autorki feministyczne stoją na stanowisku, że $-\mathrm{w}$ przeciwieństwie do płci $\mathrm{w}$ znaczeniu biologicznym (sex) - zachowania związane z płcią są wytworem społeczeństwa”, „mają źródło w społeczeństwie (kulturze), a nie w naturze" (Humm 1993, s. 164).

Wyniki badań poświęconych problematyce płci kulturowej i stereotypom płci w różnych kulturach pokazują, że w każdym społeczeństwie, w każdej kulturze funkcjonuje podział cech, zachowań, zadań i ról społecznych na męskie i kobiece (zob. Gontarczyk 1995, s. 104). Drugim powszechnikiem kulturowym jest występowanie we wszystkich społeczeństwach niższego statusu kobiet (Gontarczyk 1995, s. 104). Potwierdzają to wspominane badania antropologiczne Margaret Mead, która wykazuje, że „w poszczególnych społeczeństwach podział ról i czynności kobiet i mężczyzn jest różny, lecz niezależnie od tego, jakie role i czynności wykonują kobiety, zawsze status kobiet jest niższy, a także zawsze otrzymują one mniejsze wynagrodzenie" (Gontarczyk 1995, s. 104). Można zatem stwierdzić, za Jonathanem H. Turnerem (2004, s. 264), że „płeć biologiczna $\mathrm{i}$ jej przetworzenie $\mathrm{w}$ role łączące się $\mathrm{z}$ płcią kulturową i związane $z$ nimi wzory nierówności to uniwersalne cechy organizacji ludzkiej". Przypisywane kobietom i mężczyznom różne cechy, zadania i role społeczne pociągają za sobą nierówną partycypację $\mathrm{w}$ społecznie pożądanych dobrach, przy czym mężczyźni zawsze są kategorią uprzywilejowaną, a kobiety upośledzoną, mającą mniejszy dostęp do takich zasobów jak: „bogactwo, władza, formalne wykształcenie i kwalifikacje zawodowe, ochrona zdrowia, możliwości odpoczynku, niezależność od innych itp." (Reszke 1991, s. 12).

Jak zauważa Ewa Malinowska (2000, s. 21), „teza, że pomiędzy mężczyznami i kobietami występują wrodzone różnice, które $z$ konieczności generują fundamentalne różnice charakteru, osobowości, a co za tym idzie - losów obu płci, jest bardzo stara i stąd zapewne dość mocno utrwalona w społecznej świadomości”. Spór na temat biologicznych versus kulturowych źródeł odmiennych ról i pozycji społecznych kobiet i mężczyzn trwa od stuleci i pozostaje nierozstrzygnięty. Zwolenników miały i mają zarówno poglądy o równości, 
tożsamości płci, jak o niezbywalności różnic płciowych. Warto tu przypomnieć między innymi oświeceniową koncepcję równości płci, według której „wszelkie różnice $\mathrm{w}$ zachowaniach kobiet i mężczyzn są rezultatem procesu socjalizacji, a więc mają charakter różnic kulturowych" oraz przekonanie romantyków o naturalnych, „wrodzonych” różnicach płci, uwarunkowanych biologicznie i uzasadniających konieczność istnienia nierówności politycznej i społecznej kobiet i mężczyzn (Malinowska 2000, s. 22-27). Obie te koncepcje miały kontynuatorów także w ruchu feministycznym drugiej fali, w którym starły się ze sobą feminizm równości uznający za źródło nierówności płci kulturę - „patriarchalne ideologie, dyskryminacyjne praktyki ujawniające się już w procesie socjalizacji oraz występujące i powszechnie obowiązujące w społeczeństwie stereotypy, dotyczące podziału ról na męskie i kobiece, podziału sfer aktywności między kobiety i mężczyzn" — oraz feminizm różnicy, eksponujący inność kobiet i mężczyzn i domagający się równych praw dla kobiecości i męskości, dla kobiecej i męskiej tożsamości i podmiotowości (Malinowska 2000, s. 60, 67).

Niezależnie od kwestii wszelkich możliwych przyczyn nierówności płci nie ulega wątpliwości: mężczyźni i kobiety wciąż w nierównym stopniu uczestniczą w życiu kulturalnym, społecznym i politycznym oraz mają różny dostęp do władzy, bogactwa, prestiżu i innych cenionych dóbr, także we współczesnych demokratycznych społeczeństwach, w tym w społeczeństwie polskim. Nie chodzi tu o całkowite wykluczenie kobiet $\mathrm{z}$ udziału w sferze publicznej, z którym wiąże się partycypacja $\mathrm{w}$ zasobach, ale o istniejące utrudnienia, ograniczenia, bariery. Można mówić o dyskryminacji ze względu na płeć - o gorszym traktowaniu tylko ze względu na przynależność do określonej płci, której przypisywane są określone cechy i zachowania. Dotyczy to nie tylko kobiet, ale także mężczyzn i w ich przypadku polega na utrudnieniach w pełniejszym zaangażowaniu się $\mathrm{w}$ role rodzinne, które społecznie i kulturowo są traktowane jako domena kobiet.

Jak pokazują wyniki badań socjologicznych, istnienie nierówności płci i dyskryminacji kobiet jest podawane w wątpliwość przez dużą część społeczeństwa (Gontarczyk 1995, s. 111). Twierdzi się, że sytuacja kobiet jest obecnie lepsza niż kiedykolwiek oraz podaje się przykłady uczestnictwa kobiet $\mathrm{w}$ dziedzinach uznawanych za „męskie”, przy czym pomijany jest fakt, że uczestnictwo to często jest bardzo rzadkie, „symboliczne”.

We współczesnych demokratycznych społeczeństwach nie można mówić o równości płci w sensie równości możliwości — „równości traktowania jako sytuacji, w której wszystkie jednostki i grupy mają takie same szanse na osiąganie społecznie cenionych zasobów" (Mach 2000, s. 330). Istnieje jedynie równość polityczno-prawna (Sartori 1998). Kobiety i mężczyźni są traktowani jako pełnoprawni obywatele, mają te same prawa obywatelskie, wolności i prawa osobiste, polityczne, ekonomiczne, socjalne i kulturalne. Jak ujmuje to Ewa Gontarczyk (1995, s. 103): „W dziedzinie prawa kobiety osiągnęły poważny awans, jednakże postęp jest znacznie mniejszy w zakresie realizacji przepisów 
prawnych w praktyce". Jednak wobec równości prawa istniejące nierówności płci stają się coraz bardziej rażące, bardziej uświadomione i mniej uprawomocnione (Beck 2002, s. 152).

Przejawy nierówności statusu kobiet i mężczyzn w społeczeństwie polskim można zaobserwować w sferze prywatnej - małżeństwie, rodzinie, domu, a także $\mathrm{w}$ sferze publicznej — na rynku pracy oraz w świecie polityki, w dostępie do władzy. Stoją one w sprzeczności z prawem, które głosi równość kobiet i mężczyzn w Polsce we wszystkich tych sferach życia społecznego (art. 32 i 33 Konstytucji RP). Przyczyn takiego stanu rzeczy można się doszukiwać w tradycyjnym sposobie postrzegania przez Polaków kobiet i mężczyzn, dopuszczającym i sankcjonującym dyskryminację jednej płci i uprzywilejowanie drugiej w różnych sferach życia społecznego. Duża część polskiego społeczeństwa, jak pokazują wyniki badań społecznych, wciąż opowiada się za tradycyjnym podziałem ról i sfer działalności na męskie i kobiece (por. CBOS 2006; wyniki PGSS za: Siemieńska 2000). Najbardziej nowoczesne poglądy na role kobiet i mężczyzn w społeczeństwie mają ludzie młodzi i z wyższym wykształceniem.

\section{CEL I METODA BADANIA}

Zamierzam tu przedstawić narzędzie służące do badania postaw wobec nierównego statusu społecznego kobiet i mężczyzn oraz wyniki badania przeprowadzonego za jego pomocą wśród studentów piątego roku wybranych kierunków studiów.

Jako punkt wyjścia przyjęto (za Stefanem Nowakiem; 1973, s. 23) strukturalną definicję postawy, według której na postawę składają się trzy komponenty:

— emocjonalno-oceniający (afektywny) - „względnie trwałe dyspozycje do oceniania przedmiotu (postawy) i emocjonalnego nań reagowania"; komponent ten stanowi konieczny i wystarczający warunek istnienia postawy;

- poznawczy — „względnie trwałe przekonania o naturze i własnościach przedmiotu (postawy)";

— behawioralny — „względnie trwałe dyspozycje do zachowania się wobec przedmiotu (postawy)".

Przedmiotem badanej postawy jest nierówny status społeczny kobiet i mężczyzn w polskim społeczeństwie. W zakres terminu „społeczne nierówności płci" wchodzą konkretne przejawy nierównej pozycji, nierównych możliwości i szans przedstawicieli obu płci w różnych sferach życia społecznego w Polsce. Konkretyzacji tego pojęcia, polegającej na wskazaniu zjawisk, z którymi mamy do czynienia na co dzień w polskim społeczeństwie i do których stosuje się dany termin, służyła analiza literatury i wyników badań społecznych dotyczących problematyki nierównego społecznego statusu kobiet i mężczyzn w Polsce. Badanie postaw wobec społecznych nierówności płci jest zatem badaniem postaw wobec konkretnych przejawów nierówności płci występujących 
w różnych dziedzinach życia społecznego: w sferze prywatnej (małżeństwo, rodzina, dom), na rynku pracy oraz w dostępie do władzy.

$Z$ badania został wyłączony komponent behawioralny postawy. Można przypuszczać, że jednostki mające przekonania o określonym zabarwieniu emocjonalnym na temat społecznych nierówności płci będą w swoim dalszym życiu, zarówno na płaszczyźnie prywatnej, jak i publicznej podejmować decyzje i działania zgodne z nimi, będą podtrzymywać albo odrzucać nierówności płci, przeciwstawiać się im. Jednak nie wydaje się, by miały skrystalizowany „program działania" w tym zakresie. Kolejnym problemem są trudności z badaniem komponentu behawioralnego oraz przewidywaniem przyszłych zachowań na podstawie deklaracji. Także złożoność obiektu postawy może sprawiać, że postawa nie zawiera jasnych, uświadomionych, konkretnych dyspozycji do działania.

W tym ujęciu zatem badane postawy wobec nierówności płci w Polsce nie są postawami pełnymi ( $\mathrm{tj}$. zawierającymi wszystkie trzy komponenty). Można określić je jako postawy poznawcze - czyli „emocjonalnie naładowane przekonania o przedmiocie, bez wyraźnie skrystalizowanych predyspozycji behawioralnych" (Nowak 1973, s. 30).

Postawa należy do własności ukrytych, nieobserwowalnych, dających się zmierzyć jedynie za pośrednictwem wskaźników. Jak podaje Mirosława Marody (1976, s. 35), „najczęstszym rodzajem wskaźników występujących przy wszystkich komponentach postawy są stwierdzenia werbalne". Także w omawianym badaniu jako wskaźniki komponentu afektywnego oraz poznawczego traktowano odpowiedzi respondentów na pytania $\mathrm{w}$ ankiecie, choć trzeba zauważyć, że wśród socjologów nie ma zgody co do odpowiedzi uzyskanych za pomocą technik interrogacyjnych jako wskaźników (por. Lutyński 1994).

Komponent emocjonalno-oceniający może wyrażać się w postaci „bardziej chłodnych, zintelektualizowanych ocen”, werbalizowanych za pomocą takich określeń jak dobry/zły, słuszny/niesłuszny lub bardziej bezrefleksyjnych, „pewnych dodatnich lub ujemnych emocji”, takich jak radość, lęk, szacunek, pogarda (Marody 1976, s. 17). Badanie komponentu afektywnego postawy wobec nierówności płci ma na celu określenie, jak jednostki oceniają zjawisko nierównego statusu społecznego kobiet i mężczyzn (jako: naturalne/nienaturalne; sprawiedliwe/niesprawiedliwe; pożądane/niepożądane; słuszne/niesłuszne). Wskaźnikami są reakcje werbalne respondentów na następujące stwierdzenia dotyczące trzech sfer życia społecznego, w których występują przejawy nierówności płci:

Sfera prywatna (małżeństwo, rodzina, dom)

To naturalne, że kobiety zajmują się dziećmi i poświęcaja im więcej czasu.

To naturalne, że mężczyzna jako gtowa rodziny podejmuje decyzje w najważniejszych sprawach.

Dobrze bytoby, gdyby oboje rodzice, a nie tylko matka, korzystali $z$ urlopu wychowawczego i żadne $z$ nich nie musiato na zbyt dtugo przerywać pracy zawodowej. 
To niesprawiedliwe, że na kobietę spadaja wszystkie obowiązki zwiąane $z$ prowadzeniem domu.

Pracująca zawodowo matka może zapewnić swoim dzieciom równie dużo ciepła, co matka niepracujaca zawodowo.

Dla kobiety ważniejsze powinno być zapewnienie partnerowi warunków sprzyjajacych jego sukcesom zawodowym niż to, by mieć własne sukcesy zawodowe.

\section{Rynek pracy}

To naturalne $i$ zrozumiate, $\dot{z}$ e pracodawca mając do wyboru kobiete $i$ mężczyzne $w$ podobnym wieku, o podobnym wyksztatceniu i doświadczeniu zawodowym zatrudnia mężczyznę, bo zapewnia sobie dyspozycyjnego pracownika, który nie będzie przerywat pracy $w$ zwiazku $z$ urlopem macierzyńskim $i$ wychowawczym.

Niższy wiek emerytalny kobiet $w$ porównaniu $z$ mężczyznami jest krzywdzący dla kobiet, bo otrzymuja przez to niższe emerytury niż mężczyźni.

To przede wszystkim mężczyźni powinni obejmować kierownicze stanowiska, gdyż wykazuja się oni większym zaangażowaniem $w$ prace zawodowa $i$ lepiej nadaja się do petnienia kierowniczych funkcji niż kobiety.

Nie do przyjęcia jest wymaganie przez pracodawców oświadczeń od kobiet, że w określonym czasie nie będa miaty dzieci czy że nie będa korzystać z uprawnień opiekuńczych, takich jak urlop wychowawczy i zwolnienia na opiekę nad dziećmi.

Pracodawcy powinni równo wynagradzać kobiety i mężczyzn wykonujących podobna prace na podobnych stanowiskach.

Płeć pracownika nie powinna mieć znaczenia przy jego zatrudnianiu, liczyć sie powinny jedynie jego kompetencje, doświadczenie $i$ umiejętności niezbędne do pracy na danym stanowisku.

To naturalne, że pracodawcy pytają kobiety podczas rozmowy kwalifikacyjnej o sytuacje rodzinna, liczbę $i$ wiek dzieci czy plany prokreacyjne.

Gdy nie ma wystarczająco dużo miejsc pracy, mężczyźni maja większe do nich prawo niż kobiety.

Dostęp do władzy

Kobiety maja taki sam dostęp do władzy jak mężczyźni, tyle że niewiele z nich jest zainteresowanych polityka.

Kobiet w strukturach wtadzy jest tak mało, bo jest ich niewiele na listach wyborczych i sa spychane na dalsze pozycje, wyborcy nie maja więc często możliwości głosowania na nie.

Kobiet $w$ polityce powinno być więcej, by mogly reprezentować interesy $i$ punkt widzenia kobiet.

Kobiet $w$ polityce jest niewiele, bo wyborcy wola głosować na mężczyzn.

Płeć nie powinna decydować o wyborze danej osoby do struktur władzy, liczyć sie powinny jej kompetencje $i$ doświadczenie.

Nie potrzeba więcej kobiet $w$ parlamencie, przecież mężczyźni moga równie dobrze reprezentować kobiety. 
Kobiety powinny brać aktywny udziat w życiu publicznym, bo nadaja się do polityki tak samo jak mężczyźni.

Mężczyźni są lepszymi przywódcami niż kobiety, dlatego dominuja $w$ strukturach władzy.

Zastosowano skalę zależnościową Likerta (zob. Goode, Hatt 1965b; Mayntz, Holm, Hübner 1985). Badani ustosunkowywali się do przedstawionych opinii, deklarując jedną z pięciu odpowiedzi: „zgadzam się”, „raczej się zgadzam”, „trudno powiedzieć”, „raczej się nie zgadzam”, „nie zgadzam się”. Na ogólną skalę postawy w ankiecie składały się 22 pozycje (6 dotyczyło nierówności płci w sferze prywatnej, po 8 - nierówności płci na rynku pracy i w dostępie do władzy), które zostały wybrane $z$ dużo większej grupy przygotowanych stwierdzeń, gdyż „każda skala składa się z pozycji, które są tylko próbą ze zbioru pozycji możliwych" (Goode, Hatt 1965b, s. 259). Stwierdzenia zostały sformułowane na podstawie analizy literatury i wyników badań poświęconych problematyce nierówności płci w sferze prywatnej i publicznej w polskim społeczeństwie (3 pozycje zostały zaczerpnięte bezpośrednio z Polskiego Generalnego Sondażu Społecznego). Skala zawierała 11 stwierdzeń, których zaakceptowanie było traktowane jako wskaźnik postawy egalitarnej wobec społecznych nierówności płci (niezgoda na nie jako wskaźnik postawy nieegalitarnej), oraz 11, których odrzucenie było wskaźnikiem takiej postawy (akceptacja zaś wskaźnikiem postawy nieegalitarnej).

Punktom na skali przypisane były wartości od 1 do 5 . Wartość 5 oznaczała postawę egalitarną, wartość 1 - postawę nieegalitarną. Na przykład w przypadku stwierdzenia To naturalne, że mężczyzna jako głowa rodziny podejmuje decyzje w najważniejszych sprawach odpowiedź "nie zgadzam się" to 5 punktów na skali, "zgadzam się" - 1, natomiast przy stwierdzeniu Kobiet $w$ polityce powinno być więcej, by mogły reprezentować interesy i punkt widzenia kobiet odpowiedź, „zgadzam się" to 5 punktów, a „nie zgadzam się" - 1 .

Trzeba przypomnieć, że prawidłowo skonstruowana skala wymaga sprawdzenia ze względu na trafność (czy skala mierzy rzeczywiście to, co badacz chce zmierzyć) oraz rzetelność - dokładność pomiaru (jeżeli skala jest rzetelna, to przy każdym jej powtórzeniu powinno się uzyskać ten sam wynik) (por. Goode, Hatt 1965b; Mayntz, Holm, Hübner 1985). W przypadku skali Likerta konieczne jest także sprawdzenie jednowymiarowości skali — czy wszystkie składające się nań stwierdzenia mają tę samą wagę, czy wszystkie „mierzą interesującą nas cechę" (Goode, Hatt 1965b, s. 269; Mayntz, Holm, Hübner 1985, s. 71-72). Jednym ze sposobów jest zbadanie siły zależności między każdym z pytań a ogólną sumą punktów i włączenie do ankiety stwierdzeń o wysokim stopniu korelacji ${ }^{1}$. Po dokonaniu takiego zabiegu właściwa skala składała się

1 Do opracowywania wyniku badania afektywnego komponentu postawy nie zostały włączone stwierdzenia, dla których współczynnik $R$ Spearmana (służący określeniu zależności między zmiennymi wyrażonymi na skalach porządkowych) uzyskał wartość poniżej arbitralnie przyjętego 
z 18 stwierdzeń - po 6 dotyczących nierówności płci na trzech wspominanych płaszczyznach; zaakceptowanie dziewięciu z nich i odrzucenie dziewięciu innych traktowano jako wskaźnik postawy egalitarnej wobec społecznych nierówności płci.

Stosując do badania postaw skalę Likerta, dla każdego respondenta otrzymujemy wynik w postaci jednej liczby. Może to być suma wartości punktów zaznaczonych na skali przy każdym ze stwierdzeń lub ich średnia (dodajemy wartości zaznaczonych przez niego punktów i dzielimy przez liczbę pytań w ogólnej skali - tu 18). W omawianym badaniu posłużono się tą pierwszą wielkością (respondent mógł uzyskać wynik między 18 a 90, przy czym im bliżej 18, tym bardziej postawa respondenta wobec społecznych nierówności płci miała charakter nieegalitarny, im bliżej 90 - tym bardziej egalitarny). Wynikom liczbowym zostały przyporządkowane następujące poziomy egalitaryzmu postawy:

- 18-35 - wysoki nieegalitaryzm - ocenianie przejawów nierówności płci jako naturalnych elementów porządku społecznego, a zatem słusznych i funkcjonalnych, nie wymagających zmian, a wręcz przeciwnie - podtrzymywania i utrwalania;

- 36-53 - umiarkowany nieegalitaryzm - akceptacja wielu przejawów nierówności płci i będącego ich podstawą tradycyjnego podziału ról i sfer aktywności na męskie i kobiece;

— 54-71 — umiarkowany egalitaryzm — ocena większości zjawisk nierówności płci na różnych płaszczyznach życia społecznego jako niesprawiedliwych i niesłusznych; niezgoda na tradycyjne kulturowe definicje kobiecości i męskości;

- 72-90 - wysoki egalitaryzm - zdecydowane odrzucenie jako niesprawiedliwych, niesłusznych i niepożądanych wszelkich przejawów nierówności płci, obserwowanych zarówno w sferze prywatnej, jak i publicznej, i tym samym negacja tradycyjnego podziału ról oraz sfer aktywności na męskie i kobiece.

Komponent poznawczy postawy obejmuje wiedzę i przekonania o obiekcie postawy, jego naturze i własnościach, w tym przypadku o istniejących na różnych płaszczyznach społecznych nierówności płci. Wskaźnikami komponentu poznawczego były reakcje werbalne respondentów na następujące pytania-bodźce:

— wskazanie spośród wymienionych zjawisk przejawów nierówności płci: większe obciążenie kobiet obowiązkami związanymi z opieką nad dziećmi,

progu 0,30. Były to następujące stwierdzenia: Pteć nie powinna decydować o wyborze danej osoby do struktur wtadzy, liczyć się powinny jej kompetencje $i$ doświadczenie; Nie do przyjęcia jest wymaganie przez pracodawców oświadczeń od kobiet, że w określonym czasie nie będa miaty dzieci czy że nie będa korzystać $z$ uprawnień opiekuńczych takich jak urlop wychowawczy $i$ zwolnienia na opiekę nad dziećmi; Pracodawcy powinni równo wynagradzać kobiety i mężczyzn wykonujących podobna prace na podobnych stanowiskach. Aby zachować taką samą liczbę stwierdzeń akceptujących i negujących różne przejawy nierówności płci, wyłączono jeszcze jedno stwierdzenie nisko korelujące z ogólną punktacją skali $(0,33)-$ Kobiet $w$ polityce jest niewiele, bo wyborcy wola głosować na mężczyzn. 
większe obciążenie kobiet pracami domowymi, przyznawanie przez sądy rodzinne przede wszystkim matkom opieki nad dzieckiem w przypadku rozwodu, większe trudności kobiet ze znalezieniem pracy, nierówne traktowanie kobiet i mężczyzn w procesie przyjmowania do pracy, niższe zarobki kobiet, mała liczba kobiet na stanowiskach kierowniczych w zakładach pracy i utrudniony awans kobiet, większe zagrożenie kobiet bezrobociem, nierówny wiek emerytalny kobiet i mężczyzn, niewielki udział kobiet $\mathrm{w}$ polityce i dominacji mężczyzn w instytucjach władzy, istnienie barier utrudniających kobietom zrobienie kariery politycznej, na przykład umieszczanie ich kandydatur na dalekich miejscach na listach wyborczych;

- wskazanie, z którymi spośród wyżej wymienionych zjawisk mamy do czynienia $\mathrm{w}$ polskim społeczeństwie;

— odpowiedź na pytanie, czy obecnie kobiety w Polsce w porównaniu z mężczyznami mają większe, mniejsze czy też równe możliwości znalezienia pracy, utraty pracy, zrobienia kariery zawodowej, awansu na kierownicze stanowisko, zyskania wyższych zarobków, zrobienia kariery politycznej;

— odpowiedź na pytanie, czy więcej, tyle samo czy mniej kobiet niż obecnie powinno zajmować kierownicze stanowiska w rządzie, administracji państwowej, partiach politycznych, sądownictwie, przedsiębiorstwach przemysłowych.

Przyjęto, że na komponent poznawczy postawy egalitarnej składa się świadomość istnienia nierówności płci w Polsce oraz negatywny stosunek do tego zjawiska. Taka postawa wiąże się z przekonaniem, że nierówności płci są konsekwencją wciąż aktualnego w polskim społeczeństwie tradycyjnego podziału ról i stereotypów płciowych, a zatem są wytworem społecznym i kulturowym, a nie wynikają z różnic biologicznych między kobietami i mężczyznami. Co za tym idzie, możliwa jest zmiana istniejącego porządku i doprowadzenie do wyrównania szans i możliwości przedstawicieli obu płci. Postawa nieegalitarna $z$ kolei wiąże się z brakiem świadomości istnienia nierówności płci, a dokładniej - $z$ traktowaniem zjawisk takich jak większe obciążenie kobiet obowiązkami domowymi, utrudniony awans kobiet na kierownicze stanowiska czy bariery w zrobieniu przez nie kariery politycznej nie jako przejawów nierównego statusu społecznego kobiet i mężczyzn, lecz jako „naturalnych” i koniecznych elementów ładu społecznego. Postawa nieegalitarna zatem obejmuje pozytywny stosunek do przejawów nierówności płci w polskim społeczeństwie i ich akceptację.

\section{WYNIKI BADAŃ}

Przedstawione narzędzie do badania postaw wobec nierówności płci zostało zastosowane w badaniu przeprowadzonym w styczniu $2004 \mathrm{r}$. w grupie $150 \mathrm{stu}-$ dentów Uniwersytetu Łódzkiego, po 50 osób z piątego roku biologii, prawa i socjologii. Postawiono następującą hipotezę: kierunek studiów jest zmienną różnicującą poglądy i postawy studentów wobec społecznych nierówności płci 
w Polsce. W badanej zbiorowości studenci socjologii powinni cechować się największą „społeczną wrażliwością” i rozległą wiedzą na temat nierównego statusu społecznego kobiet i mężczyzn. Studenci prawa mogą pozycje kobiet i mężczyzn w społeczeństwie postrzegać z punktu widzenia definicji i przepisów prawnych, głoszących $\mathrm{w}$ większości równouprawnienie przedstawicieli obu płci, zatem „prawnicy” widzieć będą przede wszystkim nie nierówny status społeczny, a równy status prawny kobiet i mężczyzn w Polsce. (Najważniejszym argumentem osób twierdzących, iż problem nierówności płci nie dotyczy polskiego społeczeństwa, jest podkreślanie formalnego równouprawnienia kobiet i mężczyzn w Polsce, tak jakby gwarancja równych praw przedstawicieli obu płci $\mathrm{w}$ zapisach prawnych była równoznaczna $\mathrm{z}$ ich faktyczną równością $\mathrm{w}$ życiu społecznym). Studenci biologii wreszcie - jak sądzono - mogą postrzegać przejawy nierówności płci w społeczeństwie jako efekt naturalnych, biologicznych różnic między kobietami i mężczyznami. Obok odpowiedzi na pytanie, jakie są postawy młodych wykształconych ludzi wobec społecznych nierówności płci w Polsce, celem badania była zatem także weryfikacja hipotezy o kierunku studiów jako czynniku różnicującym sposób widzenia rzeczywistości, w tym pozycji oraz ról kobiet i mężczyzn w polskim społeczeństwie.

W punkcie wyjścia przyjęto, że studenci są świadomi nierównego statusu kobiet i mężczyzn na różnych płaszczyznach życia społecznego (komponent poznawczy postawy) i mają określony stosunek do tego zjawiska - oceniają je jako pozytywne bądź negatywne, naturalne i pożądane lub wręcz przeciwnie (komponent emocjonalno-oceniający). Założenie takie znajduje uzasadnienie w fakcie, że problem utrzymywania się nierówności płci w polskim społeczeństwie jest od dłuższego czasu nagłaśniany i podejmowane są działania (zarówno przez instytucje państwowe, jak i przez organizacje pozarządowe) mające na celu niwelowanie różnic $\mathrm{w}$ statusie społecznym kobiet i mężczyzn.

W grupie badanych przeważały kobiety $(68,7 \%$ - 103 osoby). Trzeba jednak pamiętać, że były i są one liczniej niż mężczyźni reprezentowane na wybranych do badania kierunkach studiów. Proporcje przedstawicieli obu płci kształtowały się różnie w każdej z badanych grup studentów: na biologii uczestniczyło w badaniu 11 mężczyzn, na prawie 22 i na socjologii 14 .

Celem badania była odpowiedź na następujące pytania:

1. W jakim stopniu studenci dostrzegają społeczne nierówności płci na różnych płaszczyznach życia społecznego? Czy zdają sobie sprawę z istnienia w polskim społeczeństwie takich przejawów nierówności płci jak: większe obciążenie kobiet obowiązkami związanymi z opieką nad dziećmi oraz pracami domowymi, przyznawanie przez sądy rodzinne przede wszystkim matkom opieki nad dzieckiem w przypadku rozwodu, większe trudności kobiet ze znalezieniem pracy i nierówne traktowanie kobiet i mężczyzn $\mathrm{w}$ procesie przyjmowania do pracy, niższe zarobki kobiet, utrudniony awans kobiet, nierówny wiek emerytalny kobiet i mężczyzn, niewielki udział kobiet $\mathrm{w}$ polityce i dominacja mężczyzn w instytucjach władzy, istnienie barier utrudniających 
kobietom karierę polityczną? (komponent poznawczy postawy wobec nierówności płci)

2. Jak studenci oceniają społeczne nierówności płci (jako: naturalne/nienaturalne; sprawiedliwe/niesprawiedliwe; pożądane/niepożądane; słuszne/niesłuszne)? (komponent afektywny postawy wobec nierówności płci)

3. Jaki jest stosunek studentów do instytucjonalnych form zwalczania nierówności płci, to znaczy urzędu pełnomocnika rządu do spraw równego statusu kobiet i mężczyzn oraz projektu ustawy o równym statusie kobiet i mężczyzn, a w niej propozycji wprowadzenia parytetu?

4. Czy takie cechy społeczno-demograficzne jak: płeć, kierunek studiów, poglądy polityczne, stosunek do wiary, wykształcenie matki, wykształcenie ojca oraz model rodziny pochodzenia, różnicują poglądy i postawy studentów wobec społecznych nierówności płci?

Na podstawie literatury przedmiotu i wyników wcześniejszych badań społecznych dotyczących nierówności płci w Polsce, a także własnej wiedzy i doświadczeń jako uczestniczki badanej zbiorowości (wówczas studentki piątego roku socjologii), sformułowałam następujące hipotezy:

- Większość studentów jest świadoma istnienia nierówności płci na różnych płaszczyznach życia społecznego.

- Większość studentów negatywnie ocenia istnienie nierównego statusu społecznego kobiet i mężczyzn, uważa go za niesprawiedliwy i niepożądany.

- Najbardziej egalitarni w swych postawach wobec nierówności płci są studenci socjologii.

- Postawy kobiet wobec społecznych nierówności są bardziej egalitarne niż postawy mężczyzn.

- Im wyższe wykształcenie rodziców, a przede wszystkim matki, tym wyższy egalitaryzm postawy respondenta wobec społecznych nierówności płci.

- Model rodziny pochodzenia wpływa na przekonania na temat ról kobiet i mężczyzn oraz postawę wobec nierówności płci.

- Egalitarne postawy częstsze są wśród osób o poglądach lewicowych oraz osób niewierzących i wierzących niepraktykujących niż wśród zwolenników opcji prawicowych w polityce i osób wierzących praktykujących regularnie.

- Osoby, których postawy wobec społecznych nierówności płci cechuje wysoki egalitaryzm, są zwolennikami instytucjonalnych i prawnych form zwalczania nierówności płci.

Komponent emocjonalno-oceniający postaw studentów wobec nierówności

Dokładnie połowa badanych studentów wykazała się wysoce egalitarną postawą wobec społecznych nierówności płci, to znaczy odrzucała je i oceniała jako niesprawiedliwe. Postawy 45\% respondentów można określić jako umiarkowanie egalitarne, a 5\% (7 osób) jako umiarkowanie nieegalitarne. Średni wynik postawy mierzonej za pomocą skali Likerta dla ogółu respondentów 
wyniósł 70,6, która to wielkość jest interpretowana jako wskaźnik postawy o umiarkowanym egalitaryzmie.

Najbardziej egalitarni byli studenci socjologii: wysoki egalitaryzm cechował $74 \%$ respondentów $z$ tego kierunku studiów, umiarkowany $-24 \%$. Średni wynik dla grupy badanych socjologów wyniósł 76,1. Za nimi uplasowali się studenci biologii: $54 \%$ wykazało się wysokim egalitaryzmem, umiarkowanym - 40\%. Średni wynik w tej grupie wyniósł 69,8 i mieści się w przedziale odpowiadającym postawom o umiarkowanym egalitaryzmie. Najmniej osób o wysoce egalitarnych postawach wobec społecznych nierówności płci było wśród prawników (22\%), w większości (74\%) okazali się oni umiarkowanie egalitarni. Średni wynik studentów prawa to 65,9.

Spośród kontrolowanych cech społeczno-demograficznych silny wpływ na wyniki pomiaru, obok kierunku wykształcenia, miała płeć ${ }^{2}$. Kobiety częściej niż mężczyźni przejawiały postawy wysoce egalitarne, to one w badaniu osiągnęły maksymalne wyniki na skali (63\% badanych studentek; $21 \%$ studentów). Najbardziej egalitarne, można powiedzieć, były studentki socjologii bycie kobietą i studiowanie socjologii to cechy mające silny wpływ na egalitaryzm postawy wobec społecznych nierówności płci. Wpływ innych cech społeczno-demograficznych, takich jak stosunek do wiary, poglądy polityczne, wykształcenie ojca i matki oraz model rodziny pochodzenia, okazał się słaby.

Potwierdzono zatem następujące hipotezy: postawy studentów wobec nierówności płci były egalitarne, najbardziej egalitarni okazali się studenci socjologii, częściej kobiety niż mężczyźni.

Stosunek do poszczególnych stwierdzeń składających się na skalę służącą do badania komponentu afektywnego postawy pozwala także poznać przekonania na temat roli oraz pozycji kobiety i mężczyzny w społeczeństwie, to jest $\mathrm{w}$ rodzinie, na rynku pracy, w sferze władzy politycznej. Wyniki badań społecznych pokazują, że Polacy wciąż tradycyjnie przypisują kobietom i mężczyznom „właściwe” role społeczne i sfery aktywności. Przypomnijmy, że stosunkowo najbardziej nowoczesne w swych poglądach są: kobiety, osoby młode i osoby z wyższym wykształceniem, przy czym wśród tych ostatnich skłonność do konserwatyzmu można zaobserwować u mężczyzn (Siemieńska 2000, s. 29-31). Czy takie prawidłowości powtórzyły się w omawianym badaniu? Wszyscy respondenci zdobywali wyższe wykształcenie, różnił ich jedynie kierunek studiów. Czy płeć również tu okaże się istotnym czynnikiem?

Poglądów na temat ról kobiet i mężczyzn w rodzinie dotyczyły następujące stwierdzenia: Dla kobiety ważniejsze powinno być zapewnienie partnerowi warunków sprzyjających jego sukcesom zawodowym niż to, by mieć własne sukcesy zawodowe; Pracująca zawodowo matka może zapewnić swoim dzieciom równie dużo ciepta, co matka niepracująca zawodowo. Jak stwierdza Henryk Domański (1995, s. 68), „zgoda

2 Współczynnik eta dla zależności między kierunkiem studiów a postawą wynosi 0,46, a dla zależności między płcią a postawą 0,49 . 
lub sprzeciw informują o pozytywnych - lub negatywnych — nastawieniach wobec pracy zawodowej kobiet i pozwalają wywnioskować, jaki jest stosunek do ich usamodzielniania się i emancypacji z kręgu ról, które się im tradycyjnie przypisuje". Badani studenci w zdecydowanej większości $(92 \%)^{3}$ bez względu na kierunek studiów popierali realizowanie przez kobietę własnej kariery zawodowej i sprzeciwiali się podporządkowaniu jej spraw karierze męża. Różne opinie wywołała natomiast kwestia pogodzenia przez kobiety pracy zawodowej i wychowywania dzieci. Większość badanych (65\%) stała na stanowisku, że praca zawodowa kobiet nie ma negatywnego wpływu na ich relacje $z$ dzieckiem, opiekę i wychowanie. Przekonanych o tym było $80 \%$ studentów socjologii, blisko $60 \%$ studiujących prawo i $56 \%$ biologów. Ponad jedna piąta badanych studentów uznała, że matka pracująca zawodowo nie jest $\mathrm{w}$ stanie zapewnić dziecku równie dużo ciepła jak niepracująca i mogąca być przy nim cały czas. Przeważali wśród nich studenci biologii i prawa - odpowiednio $32 \%$ i $22,4 \%$ wyraziło taką opinię.

Trzeba zauważyć, że przeciwstawianie samodzielności kobiet i ich działalności w sferze publicznej dobru dziecka jest punktem wyjścia do podtrzymywania tradycyjnego podziału ról. Kobieta robiącą karierę zawodową zawsze jest rozliczana $z$ domowych i rodzinnych ról. Ponadto sama zmaga się $z$ dylematami godzenia obu sfer życia i działalności i wyrzutami sumienia wobec niewypowiedzianych zarzutów ze strony społeczeństwa, że za jej karierę płaci dziecko. Dlatego opinię, że matka pracująca zawodowo jest gorszą matką, odrzucają przede wszystkim kobiety, przekonując same siebie, że rodzina i praca są do pogodzenia. W grupie badanych studentów na takim stanowisku stało $74 \%$ kobiet, mężczyzn natomiast oceniających równie dobrze matki pracujące i niepracujące było $45,6 \%$. Zależność między płcią a taką opinią okazała się silna $(V$ Cramera $=0,32)$.

Większość objętych badaniem studentów (59\%) uważała za naturalne, że to kobiety zajmują się dziećmi i poświęcają im więcej czasu. Taką opinię wyraziło ponad $65 \%$ prawników i biologów. Podzielone zdania mieli natomiast studenci socjologii, wśród których z powyższym stwierdzeniem zgodziło się $44 \%$, a odrzuciło je $46 \%$ respondentów. Jak można się spodziewać, kobiety częściej niż mężczyźni sprzeciwiają się owej „naturze”, która ojcostwo czyni znacznie lżejszym, obciążonym mniejszą liczbą obowiązków, choć nadal w większości taką sytuację akceptują. $Z$ opinią, że naturalne jest zajmowanie się opieką nad dziećmi głównie przez kobiety, zgodziło się $54,4 \%$ studentek i blisko $70 \%$ studentów, odrzuciło ją odpowiednio $40 \%$ badanych kobiet i $20 \%$ mężczyzn.

W przypadku pozostałych stwierdzeń dotyczących podziału ról kobiet i mężczyzn w sferze prywatnej zdecydowana większość respondentów reprezentują-

3 Jako zwolenników poszczególnych opinii potraktowano łącznie tych, którzy wskazali odpowiedź „zgadzam się” i „raczej się zgadzam”, a jako przeciwników tych, którzy wskazali odpowiedź „nie zgadzam się" i „raczej się nie zgadzam”. 
cych trzy kierunki studiów uznała, że dobrze byłoby, gdyby oboje rodzice, a nie tylko matka, korzystali $z$ urlopu wychowawczego i żadne $z$ nich nie musiało na zbyt długo przerywać pracy zawodowej (92\%), oraz oceniła jako niesprawiedliwą sytuację, w której na kobietę spadają wszystkie obowiązki związane z prowadzeniem domu (87\%). Badani studenci nie zgodzili się także w większości $z$ opinią uznającą za naturalne, że mężczyzna jako głowa rodziny podejmuje decyzje w najważniejszych sprawach $(82,5 \%)$.

Jak wynika z wcześniejszych rozważań, badani studenci przyznają kobietom pełne prawo do zajmowania się własną karierą zawodową i niepodporządkowywania jej karierze męża. Większość z nich także nie zgadza się z poglądem, że gdy nie ma wystarczająco dużo miejsc pracy, mężczyźni mają do nich większe prawo niż kobiety (73\%). Przeciwników takiego stwierdzenia najwięcej było wśród socjologów - 92\%, 64\% wśród prawników i $62 \%$ wśród biologów. Ponad jedna piąta studentów biologii (22\%) była skłonna zgodzić się, że prawo do pracy mają w pierwszej kolejności mężczyźni. Zależność między stosunkiem do tego stwierdzenia a kierunkiem studiów można określić jako raczej silną $(V$ Cramera $=0,26)$. Ciekawe wyniki daje analiza odpowiedzi kobiet i mężczyzn. Otóż, w badanej grupie sprzeciwiło się powyższej opinii nieznacznie więcej mężczyzn $(77 \%)$ niż kobiet $(71 \%)$, ponad jedna piąta mężczyzn wstrzymała się od głosu w tej sprawie, wskazując odpowiedź „trudno powiedzieć”, gdy tymczasem taka sama liczba kobiet przyznała mężczyznom pierwszeństwo do pracy. Może to być dowód na to, że młode kobiety mają silnie wdrukowane równanie: mężczyzna $=$ praca, kobieta $=$ dom i dopiero potem praca. Jak natomiast zinterpretować odpowiedzi mężczyzn? Być może tak wysoki odsetek odpowiedzi „trudno powiedzieć” wskazuje na rzeczywiste wątpliwości w definiowaniu pewnych sfer i ról jako kobiecych i męskich, związane ze zmianami zachodzącymi w kulturowych wzorach kobiecości i męskości, a może jest to tylko unik, próba zachowania politycznej poprawności. Trudno to ocenić, tym bardziej że mężczyźni w badaniu byli mniej licznie reprezentowani. Zależność między płcią a opinią na temat, czy mężczyźni mają większe prawo do pracy, można określić jako silną ( $V$ Cramera $=0,31)$.

W przypadku stwierdzeń dotyczących różnych przejawów nierówności płci na polskim rynku pracy przedstawiciele trzech wybranych kierunków studiów byli zgodni co do tego, że płeć pracownika nie powinna mieć znaczenia przy jego zatrudnianiu, liczyć się powinny jedynie jego kompetencje, doświadczenie i umiejętności niezbędne do pracy na danym stanowisku $(96,7 \%)$ oraz że pracodawcy powinni równo wynagradzać kobiety i mężczyzn wykonujących podobną pracę na podobnych stanowiskach $(98,7 \%)$. Badani studenci w zdecydowanej większości nie zgodzili się również ze stwierdzeniem, że to przede wszystkim mężczyźni powinni obejmować kierownicze stanowiska, gdyż wykazują się większym zaangażowaniem w pracę zawodową i lepiej nadają się do pełnienia kierowniczych funkcji niż kobiety (88\%). Potępili także wymaganie przez pracodawców oświadczeń, że kobiety w określonym czasie nie będą 
miały dzieci czy że nie będą korzystały z uprawnień opiekuńczych, takich jak urlop wychowawczy i zwolnienia na opiekę nad dziećmi $(94,7 \%)$. Większość respondentów negatywnie oceniła kierowane do kobiet podczas rozmowy kwalifikacyjnej pytanie o sytuację rodzinną, liczbę i wiek dzieci czy plany prokreacyjne $(62,4 \%)$, chociaż blisko jednej trzeciej uznało to za naturalne. Najwięcej przeciwników takich praktyk pracodawców było wśród socjologów $(78 \%)$, zastanawia natomiast postawa studentów prawa - aż $49 \%$ tej grupy akceptuje takie dyskryminujące kobiety postępowanie pracodawców, mimo że przecież jest ono niezgodne $z$ prawem. Czyżby znalazła tu wyraz nieznajomość prawa wśród adeptów tego zawodu, a może ignorowanie obowiązujących przepisów? Podzielone opinie wywołało stwierdzenie, że naturalne i zrozumiałe jest zatrudnianie mężczyzny przez pracodawcę mającego do wyboru kobietę i mężczyznę w podobnym wieku, o podobnym wykształceniu i doświadczeniu zawodowym, i zapewnienie sobie $w$ ten sposób dyspozycyjnego pracownika, który nie będzie przerywał pracy w związku z urlopem macierzyńskim i wychowawczym. 49\% ogółu respondentów nie zgodziło się z taką opinią, $47 \%$ natomiast zaakceptowało ją. Inaczej kształtowały się proporcje przeciwników i osób zgadzających się na powyższą sytuację w grupach studentów reprezentujących różne kierunki studiów. Jedynie wśród socjologów więcej było odpowiedzi negatywnych (65\%) niż pozytywnych (33\%), a zarówno wśród studentów biologii, jak i studentów prawa ponad połowa badanych (odpowiednio 54\% i 53\%) uznała za naturalne preferowanie przez pracodawców mężczyzn jako pracowników, ze względu na większe obciążenie kobiet obowiązkami domowymi i rodzinnymi. Trzeba tu zaznaczyć, że respondenci mieli problem z ustosunkowaniem się do tego stwierdzenia, wynikający prawdopodobnie ze sposobu jego sformułowania. Często pojawiał się komentarz, że przedstawiona sytuacja jest naturalna i zrozumiała, ponieważ często ma miejsce, i że przecież w interesie każdego pracodawcy jest zapewnienie sobie dyspozycyjnego pracownika i ograniczanie kosztów, jakie pociągają za sobą urlopy macierzyńskie, rodzicielskie i zwolnienia na opiekę nad dzieckiem, ale wzbudza sprzeciw ze względu na to, że uderza w kobiety i zmniejsza ich konkurencyjność na rynku pracy w porównaniu z mężczyznami.

Ostatnim ocenianym przez respondentów przejawem nierówności na polskim rynku pracy był różny wiek emerytalny kobiet i mężczyzn. Przypomnijmy, że większość Polaków, jak pokazują na przykład badania CBOS z marca 2002 r., uznaje wcześniejszą emeryturę kobiet za przywilej, mimo że pociąga ono za sobą znacznie niższe świadczenia emerytalne kobiet.Taki pogląd na temat zróżnicowanego wieku emerytalnego kobiet i mężczyzn w Polsce wyraziła również duża część badanych studentów. 44\% respondentów nie zgodziło się ze stwierdzeniem, że niższy wiek emerytalny kobiet jest dla nich krzywdzący, bo otrzymują przez to emerytury niższe niż mężczyźni, potwierdziło je natomiast 39\%. Blisko jednej piątej zapytanych studentów $(18,8 \%)$ nie umiało zająć konkretnego stanowiska w tej sprawie. Znowu można zaobserwować róż- 
nice w poglądach studentów poszczególnych kierunków, a przede wszystkim w opiniach socjologów oraz biologów i prawników. Wśród tych pierwszych $60 \%$ uznaje zróżnicowany wiek emerytalny za krzywdzący dla kobiet, gdy taki pogląd wyznaje $30 \%$ zapytanych studentów prawa i $26,5 \%$ studentów biologii. 55\% biologów i $48 \%$ prawników nie dostrzega dyskryminacji kobiet w ich wcześniejszym $\mathrm{w}$ porównaniu z mężczyznami przechodzeniu na emeryturę. Studenci socjologii okazują się najlepiej zorientowani w negatywnych, przede wszystkim finansowych, konsekwencjach tego rzekomego przywileju kobiet dla nich samych.

Pozostałe stwierdzenia dotyczyły nierówności płci w świecie polityki. Zdecydowana większość zapytanych studentów podzielała zdanie, że kobiety powinny brać aktywny udział w życiu publicznym, bo nadają się do polityki tak samo jak mężczyźni (95\%) oraz że płeć nie powinna decydować o wyborze danej osoby do struktur władzy, liczyć się powinny jej kompetencje i doświadczenie (98\%). Respondenci różnili się natomiast w poglądach dotyczących różnych przyczyn niedoreprezentowania kobiet w instytucjach politycznych. Jedna piąta badanych ( $28 \%$ biologów, $18 \%$ prawników i $14 \%$ socjologów) uznała, że mężczyźni są lepszymi przywódcami niż kobiety, dlatego dominują w strukturach władzy. Niemal taką samą liczbę zwolenników i przeciwników - 46,3\% i 46,9\% - miał pogląd, że kobiety mają taki sam dostęp do władzy jak mężczyźni, tyle że niewiele $z$ nich jest zainteresowanych polityką. Identyczną sytuację można było zaobserwować $\mathrm{w}$ grupie badanych prawników, natomiast $60 \%$ socjologów nie zgodziło się, że kobiet $\mathrm{w}$ polityce nie ma, bo nie są zainteresowane taką działalnością, z kolei tyle samo biologów powyższą opinię potwierdziło. Grupa badanych podzieliła się także w przypadku stwierdzenia wyjaśniającego nieliczny udział kobiet w instytucjach władzy niechęcią wyborców do głosowania na kobiety. Zgodziło się z taką opinią $40 \%$, a odrzuciło ją $37 \%$ respondentów, ponad jedna piąta nie umiała się do powyższego poglądu ustosunkować. Podzieleni w tej kwestii byli zarówno studenci biologii i prawa, jak i studenci socjologii. Inne wyjaśnienie nikłej obecności kobiet we władzy, które musieli rozważyć badani, to stwierdzenie: Kobiet $w$ strukturach wtadzy jest tak mało, bo jest ich niewiele na listach wyborczych i sa spychane na dalsze pozycje, wyborcy nie maja więc często możliwości głosowania na nie. $\mathrm{Z}$ opinią tą, potwierdzoną przez badaczy zajmujących się problematyką udziału kobiet w polityce, zgodziło się $48 \%$ zapytanych studentów, $27,5 \%$ ją odrzuciło, a ponad $24 \%$ wybrało odpowiedź „trudno powiedzieć”. Najwięcej zwolenników pogląd ten miał wśród socjologów (66\%), zaakceptowało go także 36\% studentów biologii i 43\% studentów prawa. Ostatnią kwestią, jakiej dotyczyły zawarte w ankiecie stwierdzenia, był problem znaczenia udziału kobiet w strukturach władzy. Zdecydowana większość ( $84 \%)$ respondentów (73,5\% prawników, po $90 \%$ biologów i socjologów) nie zgodziła się z opinią, że nie potrzeba więcej kobiet w parlamencie, bo mężczyźni mogą równie dobrze reprezentować kobiety. Większość respondentów (81\%) uznała także, że kobiet w polityce powinno być więcej, by mogły repre- 
zentować kobiece interesy i punkt widzenia. Stosunkowo najmniej było wśród nich prawników (65\%) i tylko ponad $18 \%$ powyższe stwierdzenie odrzuciło.

Analiza wyników badania pozwoliła zaobserwować różnice w poglądach studentów biologii, prawa oraz socjologii na temat ról kobiet i mężczyzn w społeczeństwie. Potwierdziła się też hipoteza, że studenci socjologii wyróżniają się egalitaryzmem wobec społecznych nierówności płci na tle dwóch pozostałych grup studentów.

\section{Wiedza i przekonania studentów na temat istniejących społecznych nierówności płci - komponent poznawczy postawy}

W badaniu uwzględniono także komponent poznawczy, to znaczy wiedzę i przekonania studentów na temat nierówności społecznych istniejących w różnych sferach życia społecznego w Polsce. Jednym z punktów tej części badania było ustalenie, jakie zjawiska są przez studentów traktowane jako przejawy nierówności płci. Respondenci wskazywali je, mając do dyspozycji listę dwunastu zjawisk. Zdecydowana większość badanych studentów uznała za przejaw nierówności płci niższe zarobki kobiet ( $88 \%$ wskazań), nierówne traktowanie kobiet i mężczyzn w procesie przyjmowania do pracy $(86 \%)$ oraz większe trudności kobiet w znalezieniu pracy $(80 \%)$. Wskazywano też: większe obciążenie kobiet pracami domowymi (59\%) i przyznawanie przez sądy rodzinne opieki nad dzieckiem w przypadku rozwodu przede wszystkim matkom (59\%). Na dwie niemal równe grupy badani studenci podzielili się w przypadku oceny takich zjawisk jak: oferty pracy skierowane do przedstawicieli jednej płci i większe zagrożenie kobiet bezrobociem — jedni uznali je za przejaw nierówności płci, drudzy nie. Nieco ponad połowa respondentów nie wskazała jako przejawu nierówności płci barier utrudniających kobietom karierę polityczną, na przykład umieszczania ich kandydatur na dalekich miejscach na listach wyborczych $(52 \%)$ oraz większego obciążenia kobiet obowiązkami związanymi z opieką nad dziećmi (55\%). Większość badanych wyraziła pogląd, że takich zjawisk jak niewielka liczba kobiet na stanowiskach kierowniczych w zakładach pracy (58\%), niewielki udział kobiet w polityce $(70 \%)$ oraz nierówny wiek emerytalny kobiet i mężczyzn (70\%) także nie powinno się postrzegać jako nierówności płci.

Powyższe wyniki mogą być dowodem na to, jak trudną kwestią jest ocena zjawisk spotykanych na co dzień w polskim społeczeństwie w kategoriach nierównego statusu społecznego kobiet i mężczyzn oraz dyskryminacji płci. Pokazała to także analiza stosunku studentów do stwierdzeń dotyczących przejawów nierówności płci na różnych płaszczyznach. Najmniej chyba wątpliwości wiąże się z oceną nierówności płci na rynku pracy, najwięcej się o nich mówi i doczekały się specjalnych rozwiązań prawnych mających im przeciwdziałać (przepisy znowelizowanego Kodeksu Pracy). Problemem okazuje się natomiast ocena nierównego udziału przedstawicieli obu płci w strukturach władzy. Przez większość respondentów zjawisko to nie jest oceniane jako prze- 
jaw nierówności płci. Być może jest to związane z przekonaniem, że kobiety nie są zainteresowane polityką lub że to wyborcy nie chcą kobiet $\mathrm{w}$ rolach polityków, a zatem - że za niską obecnością kobiet w świecie polityki nie stoją żadne dyskryminujące mechanizmy.

Badani studenci biologii, prawa i socjologii wskazywali także, z którymi $z$ wyżej wymienionych zjawisk mamy do czynienia w Polsce. Na podstawie ich odpowiedzi można scharakteryzować polskie społeczeństwo jako takie, w którym kobiety są bardziej niż mężczyźni obciążone obowiązkami związanymi z prowadzeniem domu i opieką nad potomstwem, a mężczyźni są dyskryminowani przez sądy rodzinne przyznające matkom opiekę nad dziećmi w przypadku rozwodu; przedstawiciele obu płci nie są tak samo traktowani w procesie przyjmowania do pracy i równo wynagradzani; kobiety mają większe trudności ze znalezieniem pracy i jest ich niewiele na stanowiskach kierowniczych $\mathrm{w}$ zakładach pracy oraz $\mathrm{w}$ polityce, wreszcie kobiety i mężczyźni przechodzą na emeryturę w różnym wieku. Wymienione zjawiska zostały wskazane przez większość respondentów (powyżej 60\%). Zjawiska, które zdaniem ponad połowy badanych studentów nie występują w polskim społeczeństwie, to: bariery utrudniające kobietom karierę polityczną, na przykład umieszczanie ich kandydatur na dalekich miejscach na listach wyborczych (58\% odpowiedzi), oferty pracy skierowane do przedstawicieli jednej płci (57\%) oraz większe zagrożenie kobiet bezrobociem. Warto zauważyć, że niektóre ze zjawisk wskazanych przez respondentów jako cechujące polskie społeczeństwo wcześniej zostały przez nich ocenione jako przejawy nierówności płci. Studenci są świadomi występowania większości z tych zjawisk, ale nie wszystkie rozpatrują w kategoriach nierówności płci, co może oznaczać, że są one dla nich naturalne i możliwe do zaakceptowania.

Poglądów na temat nierówności płci na rynku pracy dotyczyło pytanie, czy obecnie kobiety w Polsce w porównaniu z mężczyznami mają większe, mniejsze czy równe możliwości znalezienia pracy, utraty pracy, zrobienia kariery zawodowej, awansu na kierownicze stanowisko i zyskania wyższych zarobków. Przypomnijmy, że - jak pokazały wyniki przeprowadzonego w $2000 \mathrm{r}$. badania Małgorzaty Fuszary - większość Polaków, zarówno kobiet, jak i mężczyzn, ma świadomość dyskryminacji kobiet na rynku pracy (Fuszara 2002, s. 15). Świadoma tego była także większość badanych studentów. Największa część respondentów była przekonana o mniejszych szansach kobiet na awans na kierownicze stanowisko i zyskanie wyższych zarobków — odpowiednio 75\% i 73\% badanych. Duża część zapytanych studentów (63\%) zauważyła także mniejsze szanse kobiet na znalezienie pracy oraz zrobienie kariery zawodowej. Większe szanse kobiet na utratę pracy dostrzegło $57 \%$ studentów. Ta ostatnia kwestia okazała się najbardziej dyskusyjna, zwłaszcza dla studentów biologii i prawa, spośród których po $48 \%$ uznało, że zagrożenie utratą pracy dotyka w takim samym stopniu kobiety i mężczyzn, a odpowiednio $42 \%$ i $46 \%$ stwierdziło, że problem ten dotyczy bardziej kobiet. Tak podzielonych opinii nie było wśród 
badanych studentów socjologii $-84 \%$ z nich przyznało, że bardziej zagrożone bezrobociem są kobiety. Najwięcej osób, dla których sytuacja kobiet i mężczyzn na rynku pracy jest porównywalna, było wśród prawników oraz biologów ponad jedna trzecia studentów obu kierunków stwierdziła, że kobiety i mężczyźni mają takie same szanse na karierę zawodową, 36\% studentów prawa na znalezienie pracy, 34\% studentów biologii na zyskanie wyższych zarobków. Najbardziej świadomi istnienia dyskryminacji kobiet na polskim rynku pracy okazali się respondenci studiujący socjologię. Przekonanie o nierównym położeniu przedstawicieli obu płci w sferze pracy było tym silniejsze, im bardziej egalitarna była postawa wobec społecznych nierówności płci ${ }^{4}$.

Badani studenci wypowiadali się także na temat nierówności płci w świecie polityki i strukturach władzy. Zdecydowana większość (77\% - 88\% socjologów, $72 \%$ prawników i 70\% biologów) stwierdziła, że obecnie kobiety w Polsce mają $\mathrm{w}$ porównaniu $\mathrm{z}$ mężczyznami mniejsze możliwości zrobienia kariery politycznej. Podobnie uważa także blisko trzy czwarte Polaków (Fuszara 2002, s. 20). Ankietowani studenci wyrażali również swoje opinie w kwestii, czy więcej, tyle samo, czy mniej kobiet niż obecnie powinno zajmować kierownicze stanowiska w rządzie, administracji państwowej, partiach politycznych, sądownictwie oraz $\mathrm{w}$ przedsiębiorstwach przemysłowych. Odpowiedź na to pytanie można traktować jako ocenę obecnych proporcji przedstawicieli obu płci w poszczególnych strukturach władzy, a także jako opinię o konieczności zmian w tym zakresie. Większość respondentów była przekonana, że więcej kobiet niż obecnie powinno znaleźć się w parlamencie (70\%), w rządzie na stanowiskach ministrów (67\%), na kierowniczych stanowiskach w administracji państwowej (63\%), w radach nadzorczych przedsiębiorstw przemysłowych $(60 \%)$ oraz w kierownictwie partii politycznych (57\%). Połowa badanych uważała, że powinno się zwiększyć reprezentację kobiet na wysokich stanowiskach w sądownictwie, a $29 \%$, że w tej kwestii nic nie trzeba zmieniać. Należy tu zaznaczyć, że pytanie o liczbę kobiet w różnych instytucjach władzy sprawiło trudność sporej części respondentów, odsetki odpowiedzi „trudno powiedzieć” w niektórych przypadkach sięgały $20 \%$.

Wśród respondentów dostrzegających potrzebę większej reprezentacji kobiet we wszystkich wymienionych instytucjach władzy dominowali studenci socjologii. Najwięcej osób akceptujących status quo i niechętnych zwiększaniu reprezentacji kobiet $\mathrm{w}$ niektórych gremiach decyzyjnych znalazło się wśród zapytanych prawników. Jedna czwarta tej grupy stała na stanowisku, że dotyczy to Sejmu i Senatu oraz kierowniczych stanowisk w administracji państwowej. Ponad jedna piąta badanych studentów prawa, a także biologii wyraziła prze-

4 Zależność tę można określić jako silną. Współczynnik eta dla zależności między wskaźnikiem postawy a odpowiedziami na pytanie, czy obecnie kobiety w Polsce w porównaniu $z$ mężczyznami mają większe, mniejsze czy równe możliwości znalezienia pracy, utraty pracy, zrobienia kariery zawodowej, awansu na kierownicze stanowisko i zyskania wyższych zarobków, przyjmował wartości $0,48-0,61$. 
konanie, że obecnie wystarczająca liczba kobiet znajduje się w radach nadzorczych przedsiębiorstw. Co ciekawe, 35\% zapytanych prawników uznało, że nie potrzeba więcej kobiet na najwyższych szczeblach władzy sądowniczej. Zwiększenie zaś liczby kobiet na tych stanowiskach postulowało $40 \%$ tej grupy ( $46 \%$ kobiet i $30 \%$ mężczyzn). Warto zauważyć, że także ponad jedna piąta biologów i 30\% socjologów uważało obecną liczbę kobiet na wysokich stanowiskach w sądownictwie za odpowiednią. Być może wynika to z przekonania, że akurat w tej dziedzinie kobiety nie stanowią mniejszości, mimo że analiza składów osobowych takich organów władzy sądowniczej jak Sąd Najwyższy, Naczelny Sąd Administracyjny, Krajowa Rada Sądownictwa, Trybunał Konstytucyjny czy Trybunał Stanu wyraźnie pokazuje dominację mężczyzn. A może jest to wyraz poczucia, że to jednak mężczyźni sprawdzają się w takich rolach lepiej od kobiet.

Podsumowując tę część rozważań, można powiedzieć, że większość studentów dostrzegła przejawy nierówności płci w polskim społeczeństwie, zarówno w sferze prywatnej, jak i publicznej - na rynku pracy i w świecie polityki. Wyniki te potwierdzają tym samym stawianą hipotezę oraz prawidłowości zaobserwowane przez innych badaczy — osoby młode i osoby z wyższym wykształceniem są najbardziej świadome nierówności statusu społecznego kobiet i mężczyzn. Najwyższą świadomością w tej kwestii wyróżnili się studenci socjologii.

Stosunek studentów do instytucjonalnych form zwalczania nierówności płci

Przedstawione wyniki badania pokazują, że studenci to osoby o nowoczesnych poglądach w kwestii sfer aktywności oraz ról społecznych kobiet i mężczyzn, a także wykazujące się egalitaryzmem postaw wobec społecznych nierówności płci. Warto przekonać się, czy te cechy przekładają się na poparcie dla instytucjonalnych form zwalczania nierówności płci, to znaczy urzędu pełnomocnika rządu do spraw równego statusu kobiet i mężczyzn oraz projektu ustawy o równym statusie kobiet i mężczyzn, a w niej propozycji wprowadzenia parytetu.

Jak pokazują wyniki badania przeprowadzonego przez CBOS wkrótce po utworzeniu urzędu pełnomocnika rządu do spraw równego statusu kobiet i mężczyzn w lutym 2002 r., opinie Polaków co do konieczności istnienia takiej instytucji są podzielone - $45 \%$ uważało ją wówczas za potrzebną, a $36 \%$ za niepotrzebną. Potrzebę stworzenia urzędu dostrzegały przede wszystkim osoby młode, negowali ją natomiast ludzie z wyższym wykształceniem. W badaniu przeprowadzonym wśród studentów biologii, prawa i socjologii większość respondentów (74\%) opowiedziała się za istnieniem urzędu pełnomocnika rządu do spraw równego statusu kobiet i mężczyzn. Najmniej zwolenników tej instytucji było wśród prawników - ponad jedna trzecia tej grupy (35\%) uznała ją za niepotrzebną, podczas gdy wśród socjologów i biologów odsetek osób 
wyrażających taki pogląd wynosił $14 \%$. Stosunek do tej kwestii wiąże się z postawą wobec społecznych nierówności płci - wysoki egalitaryzm sprzyja opinii o konieczności istnienia urzędu pełnomocnika ${ }^{5}$.

Studenci biologii, prawa i socjologii byli także pytani o ich stosunek do projektu ustawy o równym statusie kobiet i mężczyzn, a w niej propozycji wprowadzenia parytetu. Połowa respondentów (51\%) wyraziła przekonanie, że potrzebna jest odrębna ustawa, gwarantująca kobietom i mężczyznom takie same prawa oraz równe traktowanie w życiu publicznym, rodzinnym i w pracy, bo zapis o równości płci w konstytucji jest niewystarczający dla ochrony praw kobiet. Ponad jedna trzecia (37\%) ogółu badanych studentów stwierdziła, że nie ma potrzeby tworzenia nowej ustawy i że wystarczy zapis o równości płci w konstytucji. Warto zauważyć, że odwrotną tendencję zaobserwowano w badaniu opinii społeczeństwa polskiego na ten temat — w sondażu CBOS (2002) jedynie co trzeci Polak uznał nową ustawę za potrzebną, a większość (59\%) była zdania, że dla ochrony praw kobiet wystarczy konstytucyjny zapis o równości płci. Przeciwników nowego aktu prawnego było najwięcej (53\%) wśród osób studiujących prawo. W interpretacji może tu być pomocny komentarz jednego $z$ respondentów studiujących na tym kierunku - stwierdził on, że tworzenie odrębnej ustawy nie ma sensu, bo kwestia równości płci jest już podejmowana w innych aktach prawnych, a zatem powinno się wprowadzać przepisy wykonawcze, umożliwiające egzekwowanie zapisanych praw. Trzeba jednak dodać, że z pytaniem, co to $\mathrm{w}$ ogóle za ustawa i czemu ma służyć, zetknięto się jedynie wśród prawników, co wskazywałoby na ich brak zorientowania, że tak obszerny przecież akt prawny kilkakrotnie już był dyskutowany i że były podejmowane próby jego wprowadzenia. Za ustawą najczęściej opowiadali się studenci socjologii (68\%), a następnie studenci biologii (52\%). Silny wpływ na stanowisko respondenta $\mathrm{w}$ tej sprawie miała jego płeć oraz postawa wobec nierówności płci 6 - stworzenie ustawy popierały częściej kobiety niż mężczyźni (odpowiednio 64\% i 22\%) oraz osoby o wysoce egalitarnych postawach.

Respondenci odpowiadali także na pytanie, czy według nich powinno się podjąć działania zmierzające do zwiększenia udziału kobiet w życiu publicznym. W badaniu Małgorzaty Fuszary (2002, s. 27) połowa zapytanych o to Polaków uznała takie działania za niezbędne, ponieważ kobiety mają mniejsze możliwości udziału w życiu publicznym niż mężczyźni, a ponad jedna trzecia polskiego społeczeństwa nie zgodziła się na to, chociaż popiera udział kobiet w polityce. Badani studenci tym razem nie podzielili stanowiska ogółu Polaków: ponad połowa (53\%) odrzuciła taki pomysł, przy czym takie stanowisko

5 Zależność między poglądem na temat konieczności istnienia urzędu a postawą wobec nierówności płci jest silna, współczynnik eta wynosi 0,63.

6 Współczynnik zależności między odpowiedzią na to pytanie a płcią respondenta $V$ Cramera wynosi 0,46, a współczynnik zależności między odpowiedzią na to pytanie a egalitaryzmem postawy wobec nierówności płci eta osiągnął wartość 0,61. 
zajęła zdecydowana większość zapytanych prawników (72\%), połowa biologów i ponad jedna trzecia (36\%) socjologów. Za podjęciem działań mających prowadzić do większej obecności kobiet w świecie polityki opowiedziało się $43 \%$ ogółu ankietowanych studentów - dominowali wśród nich studenci socjologii (60\% poparło takie działania).

Badani studenci podzielili się także w kwestii kwotowego udziału kobiet w rządzie i w ważnych instytucjach państwowych i publicznych oraz na listach kandydatów do Sejmu, Senatu i samorządów. $40 \%$ ankietowanych uznało prawne zagwarantowanie kobietom określonej liczby miejsc w ważnych instytucjach państwowych i publicznych za sprawiedliwy sposób zmniejszenia dyskryminacji, a $35 \%$ odrzuciło taki pomysł, traktując go jako nieusprawiedliwione uprzywilejowanie kobiet. Jedna czwarta zapytanych studentów nie umiała zająć żadnego stanowiska w tej sprawie. Więcej zwolenników wprowadzenia w Polsce parytetu podczas obsadzania ważnych stanowisk publicznych znalazło się wśród badanych studentów socjologii (46\%) oraz biologii (45\%), mniej w grupie prawników (29\%), którzy najczęściej uznawali takie działania za nieusprawiedliwione uprzywilejowanie jednej płci (47\%). Przypomnijmy, że w badaniu CBOS (2002) większość Polaków (55\%) odrzuciła propozycję parytetu, a zaakceptowała ją jedna trzecia społeczeństwa.

Badani mieli trudności $\mathrm{z}$ zajęciem określonego stanowiska także $\mathrm{w}$ przypadku oceny pomysłu, aby w wyborach ustawowo zagwarantować kobietom odpowiednią liczbę miejsc na listach kandydatów do Sejmu, Senatu i samorządów - jedna trzecia ankietowanych wybrała odpowiedź „trudno powiedzieć”. Pozostali podzielili się - 37\% uznało powyższy pomysł za dobry, $30 \%$ za zły. Przeciwników zagwarantowania kobietom określonej liczby miejsc na listach wyborczych najwięcej było wśród studentów prawa (41\%). Pomysł taki poparła natomiast połowa zapytanych studentów socjologii i $41 \%$ studentów biologii. Badani prawnicy okazali się zatem najbardziej niechętni wszelkim propozycjom dyskryminacji pozytywnej — tymczasowych szczególnych przepisów zmierzających do przyspieszenia faktycznej równości kobiet i mężczyzn (Sto haseł 2000, s. 12). Natomiast najwięcej osób popierających takie rozwiązania znalazło się wśród studentów socjologii. Na poglądy w kwestii podejmowania specjalnych działań prawnych na rzecz zwiększania udziału kobiet w życiu publicznym silny wpływ ma płeć oraz postawa wobec nierówności płci 7 . Kobiety oraz osoby o wysokim egalitaryzmie postaw wobec społecznych nierówności płci dominują wśród zwolenników takich działań.

7 Współczynnik $V$ Cramera dla zależności między płcią a odpowiedziami na powyższe pytania osiągnął wartość powyżej 0,43. Wartość współczynnika eta określająca siłę zależności między egalitaryzmem postawy a odpowiedziami na te pytania wynosi odpowiednio $0,56,0,54$ oraz 0,50. 
Wyniki badania przeprowadzonego w grupie studentów prawa, biologii i socjologii nie pozwalają wypowiadać się o całej zbiorowości młodych ludzi kończących studia. Na ich podstawie można jednak stwierdzić, że nie tylko poziom wykształcenia (jak pokazują chociażby sondaże CBOS), ale także jego kierunek ma wpływ na poglądy dotyczące ról kobiet i mężczyzn w społeczeństwie - socjologowie znacznie różnią się w swych opiniach od prawników i biologów. Ciekawe byłoby sprawdzenie, jakie postawy wobec nierówności płci mają osoby studiujące na innych kierunkach. Warto byłoby także uzupełnić badanie ankietowe technikami niestandaryzowanymi, jak wywiady swobodne czy zogniskowane wywiady grupowe, by obok porównania postaw i poglądów móc poznać ich uzasadnienia, uzyskać pogłębione, spontaniczne wypowiedzi.

Wyniki badania potwierdzają tendencję zaobserwowaną w sondażach przeprowadzanych na reprezentatywnych próbach Polaków - młodzi wykształceni ludzie mają nowoczesne poglądy na temat ról i sfer aktywności kobiet oraz mężczyzn i odrzucają tradycyjne społeczne definicje kobiecości i męskości. Nie zgadzają się także na większość występujących w polskim społeczeństwie przejawów nierówności płci, mają egalitarne postawy w kwestii społecznego statusu kobiet i mężczyzn. Jak się jednak okazuje, nie jest to jednoznaczne $z$ ich zgodą na instytucjonalne formy walki z nierównościami płci. Wątpliwości wzbudza przede wszystkim idea parytetu i zastosowania środków tzw. dyskryminacji pozytywnej. Prawdopodobnie wynika to z przekonania, że takie działania są niedemokratyczne (por. Malinowska 2000), który to pogląd podzielają przede wszystkim osoby z wyższym wykształceniem. Być może organizacje i instytucje działające na rzecz wprowadzenia parytetu, wiedząc o tego typu obawach dużej części społeczeństwa, powinny bardziej przybliżyć tę ideę i pokazać, jak przebiega wcielanie jej w życie $\mathrm{w}$ innych krajach europejskich.

Pozostaje jeszcze pytanie, czy egalitarne poglądy i postawy badanych studentów wobec społecznych nierówności płci pociągną za sobą egalitarne zachowania, gdy młodzi ludzie będą zakładać własne rodziny, wchodzić na rynek pracy, angażować się $\mathrm{w}$ działalność publiczną. Wówczas okaże się, czy deklaracje egalitaryzmu pozostaną deklaracjami, czy będą realizowane $\mathrm{w}$ codziennym życiu. Wydaje się, że przede wszystkim od młodych wykształconych kobiet można oczekiwać, iż nie będą zgadzać się na nierówności płci na różnych płaszczyznach życia społecznego i zadowalać się aktywnością $\mathrm{w}$ sferze prywatnej, tym „królestwie kobiet”, że będą protestować przeciwko „szczególnemu" traktowaniu przez pracodawców i coraz liczniej wkraczać w świat polityki, nie traktując go jako sfery zarezerwowanej dla mężczyzn. Można też mieć nadzieję, że badani studenci - młodzi wykształceni mężczyźni będą realizować zasady równości i partnerstwa w swoich małżeństwach, że nie pozwolą, by ich koleżanki „po fachu” były przez pracodawców traktowane inaczej niż oni sami, a w polityce będą traktować je jako równorzędnych partnerów. Czas pokaże... 


\section{BIBLIOGRAFIA}

Beck Ulrich, 2002, Społeczeństwo ryzyka. W drodze do innej nowoczesności, tłum. Stanisław Cieśla, Scholar, Warszawa.

CBOS, 2002, Opinie o polityce rządu wobec kobiet. Komunikat z badań, Warszawa, luty.

CBOS, 2002, Opinie o wieku emerytalnym kobiet i mężczyzn. Komunikat z badań, Warszawa, marzec.

CBOS, 2006, Potrzeby prokreacyjne oraz preferowany i realizowany model rodziny. Komunikat z badań, Warszawa, marzec.

Domański Henryk, 1992, Zadowolony niewolnik? Studium o nierównościach ptci między mężczyznami $i$ kobietami w Polsce, IFiS PAN, Warszawa.

Domański Henryk, 1995, Równouprawnienie. Stereotyp tradycyjnego podziału ról, w: Anna Titkow, Henryk Domański (red.), Co to znaczy być kobieta w Polsce?, IFiS PAN, Warszawa.

Dzwonkowska Krystyna, 2004, „Zbudować społeczeństwo egalitarne. Postawy studentów wobec nierówności płci w Polsce”, praca magisterska napisana pod kierunkiem dr hab. Ewy Malinowskiej, Biblioteka Instytutu Socjologii, Uniwersytet Łódzki, Łódź.

Fuszara Małgorzata, 2002, Zmiany w świadomości kobiet w Polsce w latach 90., w: Małgorzata Fuszara (red.), Kobiety $w$ Polsce na przełomie wieków. Nowy kontrakt ptci?, Instytut Spraw Publicznych, Warszawa.

Giddens Anthony, 2004, Socjologia, tłum. Alina Szulżycka, Wydawnictwo Naukowe PWN, Warszawa.

Gontarczyk Ewa, 1995, Kobiecość i męskość jako kategorie społeczno-kulturowe w studiach feministycznych, Eruditus, Poznań.

Goode William J., Hatt Paul K., 1965a, Postawowe problemy pomiaru, w: Stefan Nowak (red.), Metody badań socjologicznych, PWN, Warszawa.

Goode William J., Hatt Paul K., 1965b, Skala zależnościowa Likerta, w: Stefan Nowak (red.), Metody badań socjologicznych, PWN, Warszawa.

Humm Maggie, 1993, Słownik teorii feminizmu, tłum. Bożena Umińska, Jarosław Mikos, Semper, Warszawa.

Lutyński Jan, 1994, Metody badań społecznych. Wybrane zagadnienia, Łódzkie Towarzystwo Naukowe, Łódź.

Mach Bogdan W., 2000, Równość i nierówność społeczna, w: Encyklopedia socjologii, t. 3, Oficyna Naukowa, Warszawa.

Malinowska Ewa, 2000, Feminizm europejski, demokracja parytetowa a polski ruch kobiet, Wydawnictwo Uniwersytetu Łódzkiego, Łódź.

Marody Mirosława, 1976, Sens teoretyczny a sens empiryczny pojęcia postawy, PWN, Warszawa.

Mayntz Renate, Holm Kurt, Hübner Peter, 1985, Wprowadzenie do metod socjologii empirycznej, tłum. Wanda Lipnik, PWN, Warszawa.

Nowak Stefan, 1973, Pojecie postawy $w$ teoriach $i$ stosowanych badaniach społecznych, w: Stefan Nowak (red.), Teorie postaw, PWN, Warszawa.

Reszke Irena, 1991, Nierówności ptci $w$ teoriach, IFiS PAN, Warszawa.

Sartori Giovanni, 1998, Teoria demokracji, tłum. Piotr Amsterdamski, Daniel Grinberg, Wydawnictwo Naukowe PWN, Warszawa.

Sekuła-Kwaśniewicz Halina, 2000, Płeć, w: Encyklopedia socjologii, t. 3, Oficyna Naukowa, Warszawa. 
Siemieńska Renata, 2000, Nie moga, nie chca czy nie potrafia? O postawach $i$ uczestnictwie politycznym kobiet $w$ Polsce, Scholar, Warszawa.

Sto haseł, 2000, Sto haset o równości. Podręczny stownik pojęć dotyczących równości kobiet $i$ mężczyzn $w$ sferze zatrudnienia $i$ polityki spotecznej, równych szans $i$ polityki rodzinnej, Stowarzyszenie Kobiet na rzecz Równego Statusu Płci - Pekin 1995, Warszawa. Turner Jonathan H., 2004, Struktura teorii socjologicznej, tłum. Grażyna Woroniecka i in., Wydawnictwo Naukowe PWN, Warszawa.

Walczewska Sławomira, 2001, Trudne stowo gender, „Zadra” nr 3-4.

\section{THE ATTITUDES OF STUDENTS OF DIVERSE DEPARTMENTS TOWARDS THE INEQUALITY OF THE SEXES IN POLAND}

\section{Summary}

Examples of sexual inequality in Polish society can be found in private (the family and the household) and in public spheres (at work or in access to authority). The proposed tools for testing the attitudes towards inequality between men and women involves surveying convictions concerning the existing sexual inequality in society (the cognitive component of the attitude) and the reactions to it (the emotional component of the attitude). As a result it is possible to define the awareness of the existence of sexual inequality and the level of egalitarianism in the attitude towards it. The article describes the use of this tool in testing the attitudes of students of diverse department of the university

\section{Key words/słowa kluczowe}

sex / płeć biologiczna; gender / płeć kulturowa; gender equality / równość płci; gender inequality / nierówność płci; attitude / postawa 